\title{
Age War as the New Class War? Contemporary Representations of Intergenerational Inequity
}

\author{
SUSAN PICKARD \\ Department of Sociology, Social Policy and Criminology, University of Liverpool, Eleanor \\ Rathbone Building, Bedford Street South, Liverpool, Merseyside L69 7ZA, United Kingdom \\ email: susan.pickard@liverpool.ac.uk
}

\begin{abstract}
This paper examines intergenerational justice discourses that feature prominently in both the contemporary UK media and beyond, arguing that these constitute both a continuation of previous debates about the economic and social burden of the dependent 'fourth age' and a newer and more prominent denigration of the 'third age', both of which possess deep cultural and psychological roots. Both themes are subsumed in the trope of the old as in some ways stealing the future of the nation, represented by youth. Analysing media depictions of intergenerational injustice across several themes, the paper suggests that, whilst justifying welfare retrenchment and other aspects of neoliberalism, the portrayal of social problems in terms of generational war emerges from age ideology and an age system that, among other things, intersects with and naturalises other forms of stratification. This partly accounts for the fact that the attack on the 'third age' is particularly prevalent in left of centre, or progressive, media on both sides of the Atlantic. That the age system has been overlooked and underplayed in sociological terms is an important oversight since the former materially and ideologically facilitates the ever-growing socio-economic inequality that is a feature of our times.
\end{abstract}

\section{Introduction}

\section{Problematising the third age}

Discourses in the UK media and popular texts depicting forms of intergenerational injustice wherein the 'old' are depicted as taking a disproportionate and 'unfair' segment of the nation's wealth, which impedes the life chances of the young, have become exceedingly commonplace in the UK and other advanced liberal nations. Criticism of the old in the UK in the 1980 os and 1990 s was directed mostly at the costs of pensions, health and social care and at the 'burden' this represented for the rest of society. There has been a notable broadening of such critiques since 2008's financial crisis, and the subsequent introduction of austerity measures, so that they now include the older generation's unfair political influence and success at the ballot box, their advantageous housing, education and pension 
capital and, in existential terms, their privileged amounts of lifetime luck and success. At the same time such criticism of the youthful 'third age' has become one of the main ways of depicting the older generation in advanced capitalist nations such as the UK, North America, Australia and New Zealand (e.g. Hurley et al., 2017; Macnicol, 2015b). This trend is particularly worrying as welfare states are founded upon an implicit intergenerational contract, which is being eroded through this discourse. It is an inaccurate representation as it homogenises age categories, overlooking the extent to which they are internally stratified by class, gender and other features. Furthermore, such an approach suggests ontological difference and discontinuity rather than perceiving age groups as different points along the same lifecourse. A recognition of commonalities and continuities, by contrast, would illuminate how both young and old people are suffering the effects of social inequality, albeit in different ways. The former, for example, endure high rates of unemployment and student debt whilst being priced out of the housing market, and the latter experience high job insecurity if they are in work, high levels of redundancy and/or unemployment if they are looking for work over the age of 50 or, if they are retired, below-inflation rates for savings and the collapse of many final-salary occupational schemes. Indeed, inequality is a feature throughout the lifecourse, leading John Macnicol to observe: 'Applying some kind of misery index and deciding which group is a winner, and which a loser, is well-nigh impossible' (2015a: 230).

The media depiction of the old(er) generation(s) - a deliberately fuzzy category which can encompass anyone aged approximately 45 and over (but sometimes much younger ${ }^{1}$ ), as well as the 'baby boomer' generation (those born between the end of the Second World War and the mid-1960s) or those who have retired, depending on the issue at hand - continues a long-established tendency to scapegoat 'the old' in times of uncertainty, social change and economic retrenchment. For example, discourses of generational conflict were prominent in the USA during the 1980 os period of neoconservative welfare retrenchment, assisted by pressure groups such as Americans for Generational Equity (AGE) and prominent in publications by the OECD and the World Bank. Such discussion focused on their taking up too much health care provision (Callahan, 1987) and on their material and social privileges (Cole, 1989). The 'privilege' critique was less pronounced in the UK at that time despite Prime Minister Margaret Thatcher's attempt to encourage this discourse (Phillipson, 1996). However, since 2008 comparable rhetoric has appeared in the UK media, as well as in statements by pressure groups such as the Intergenerational Foundation and, less stridently, the Resolution Foundation, adding a further threat to the discourse of 'apocalyptic demography': that of 'successful ageing'. The context for this, in addition to ageing populations and disinvestment in public services, is a growing social inequality, which makes the UK the European country most like the USA in this respect, with an income gap between the richest and the rest 
of a magnitude that has not been seen in the UK since 1918 (Dorling, 2014: 1). Rhetorical justification of such inequality, by the global elites that benefit from it, includes claims to a 'trickle down' effect. However, the role played by discourses stressing the culpability of ordinary older citizens in this process, including those who have fulfilled imperatives to remain active, healthy and productive, also serves to legitimate both such elites and the capitalist economy from which they profit.

\section{Background}

\section{Evidence of intergenerational inequity}

As noted, evidence for intergenerational inequity remains highly contestable, not least in the terms in which it is framed, where, for example, the older generation is considered to be directly responsible for socio-economic difficulties faced by the young. In contemporary times certainly the young, or 'millenials' are experiencing a wealth of problems including the cost of higher education, insecure jobs, high rents and property prices combined with shortage of housing. But that this is the 'fault' of the older generation, 'baby boomers' or others, is deeply inaccurate. Keeping house prices high has been a consistent government aim; university fees were introduced by Labour's social mobility Tsar Alan Milburn; youth unemployment was high in the 1970s and 1980s; housing shortages and the gig economy in the UK in particular can be attributable to globalisation, both in terms of the purchasing of real estate and in terms of the movement of labour into cities which then pushes house prices up (Macnicol, 2015b). All of this means that the challenges faced by the millenials are in fact structural, and not that government policy has been formulated specifically to favour the 'old' (Macnicol, 2015b). Evidence further refutes many of the claims regarding baby boomers' so-called 'privilege' including in education (just over 13 per cent of those aged 65-69 have a degree); finances (30 per cent of those aged between 55 and 64 do not have any private pension, affecting 37 per cent of women as compared to 19 per cent of men); and housing stock (one-quarter of those aged between 55 and 64 live in rented accommodation and under a half own their property outright) (Sinclair, 2015). More important, however, is the internal stratification evident. Taking just one of the categories - pensions - there is a polarisation in four major ways relating to a striking difference in wealth between:

- those with private pensions and those without;

- private pension types (Defined Benefits or Defined Contributions);

- occupational class; and

- genders (Financial Conduct Authority (FCA), 2017).

Older women suffer most from the effects of structural disadvantage, both in relation to men and to younger women: the gender pay gap increases with age, 
being twice as large for women in their 50 s as for women overall. The former are more likely, both compared to men of their own age and younger women, to be in the ranks of the long-term unemployed, with class disadvantages adding to this (TUC, 2013). In retirement in the UK, 13 per cent of women qualify for the full basic state pension (which is already the lowest of any OECD country (OECD, 2017)), and half of what a worker on 40 hours a week would earn annually on the minimum wage) compared with 92 per cent of men (Thane, 2006). ${ }^{3}$

\section{The role of the media}

In the UK, the media has played a very significant role in shaping the increasingly entrenched consensus around intergenerational inequity. In terms of everyday belief, the media is 'key to the setting of agendas and focusing public interest on particular subjects, which operates to limit the range of arguments and perspectives that inform public debate' (Happer and Philo, 2013: 321). Since 2008 the mainstream media has given a prominent role to City voices, which has resulted in general support for austerity policies and government retrenchment (Berry, 2010). The media's influence is likewise significant in shaping public attitudes towards older age groups. Here some shift in emphasis is visible pre-and post-2008. Examining discourses in 2008 in the Irish media on the subject of proposed legislation to reduce welfare provision for older people, Fealy and colleagues (2012) found that negative stereotypes concerning older people predominated. Whilst there were some positive stereotypes, such as old age as a golden period of leisure, depictions of older people as frail, cognitively impaired and/or a burden on society were far more frequent. This was consistent with a study that found that, in two-thirds of their articles on older people in the eleven-year period to 2008, The Economist depicted them as a burden on society (Martin et al., 2009; quoted in Fealy et al., 2012). However, as noted, following the advent of post-crash/austerity measures in 2009 the emphasis switched to negative representations of third-agers in terms of privilege. For example, Hurley and colleagues (2017) found, through an analysis of New Zealand media coverage of super-annuation debates, that the rhetoric of intergenerational equity arguments proceeded by depicting baby boomers as fortunate, successful and powerful in ways that were unjust in generational terms, whilst employing such terms to define a whole cohort.

In terms of the media, there are two factors of particular note. Firstly, individual columnists across a range of printed and online newspapers are unusually important claims-makers in the construction of the third age as well as baby boomers (although the two are not synonymous) as a social problem (Bristow, 2015). Indeed, Bristow suggests that, in the case of the UK, the baby boomer/third age problem originated in the media and has only later been taken up by campaign groups, contrary to the classic social problem model whereby this role usually falls to campaigning or influence groups (Best, 2008). Secondly, 
such representations are particularly prominent in the progressive media. The reasons for this, I argue, stem to a large degree from a cultural antipathy to ageing and old age embedded in modernity and, importantly, depicted as a brake to progress and radicalism. This antipathy arises from an age system and associated age ideology which underpins western intellectual categories, institutions and everyday psychological dispositions and which favours the narrative of 'progress' with an associated valorisation of youth (Gullette, 1997). However, unlike other modes of stratification, such as patriarchy, the age system has not been so readily identified as a source of inequality, and age-based distinctions are still overwhelmingly understood as natural and inevitable, rather than constructed and contestable. The age system has thus played a key role in legitimating transnational capitalism and in channelling public anger away from class to so-called age inequality. Before turning to media representations of old age, I pause to discuss the age system in more detail.

\section{The age system}

Throughout western modernity, the age system has both regulated populations in line with the needs of capitalism, disciplining the workforce and latterly shaping consumer identities, and has served to inject meaning into an increasingly disenchanted existence (Cole, 1992). The age system is a hierarchically constituted mode of governance, operating through the framework of the lifecourse, in which the role of particular ages and their relationship to each other underpins and legitimises an assortment of material and other inequalities (Calasanti and Slevin, 2006; Gullette, 1997; Pickard, 2016). For example, both the younger and older populations have served as a reserve army of labour; unwillingness to invest in an older labour force, either in terms of training or by providing the flexibility that would support (particularly female) workers' caring obligations, in turn justifies poor conditions and underpins claims regarding their 'natural' obsolescence. The lifecourse plays a key role in organising individuals and groups into seemingly natural age-based categories, based on a temporal narrative of growth, stability/stasis and decline, but whose contingency is revealed through a historical gaze. For example, the 'invention' of youth as a stage of life defined in relation to education, symbolically constituted in terms of the 'future of the nation', only began to take the shape it possesses today in the course of the late nineteenth and early twentieth centuries (Cunningham, 2006). Similarly, within the same period, old age as a category was given meaning and substance in relation to the institution of retirement as well as the discourses of geriatric medicine that established a different ontology for older bodies (Katz, 1996). In late modernity, the institutional lifecourse has been replaced by a more fluid concept, and education and retirement as the 'boxes' containing youth and old age respectively no longer apply with such determinacy. Beneath the fluidity, however, lies a new structure, namely that of neoliberalism, with an emphasis 
on individual productivity, success and entrepreneurial qualities expected at all ages and stages and in all contexts, including unemployment, ill health and retirement.

The resultant 'neoliberalisation' of old age (Macnicol, 2015b) has been accompanied by the construction of the 'third' and 'fourth' age categories, defined according to a distinction between biological (amenable to lifestyle and selfcare practices) and chronological dimensions, with successful ageing displaying biological and other characteristics of youthfulness (Rowe and Kahn, 1987). Although in contemporary times these distinct categories have been shaped by medical discourses they can be traced back as far as the nineteenth century where a split between a 'good' and 'bad' old age associated 'virtue' with ageing well (Cole, 1992). In contemporary times such moral underpinnings remain and the third age is characterised by levels of autonomy, youthfulness, consumerism/productivity and health. By comparison the fourth age is defined as a loss of all these attributes. 'Choice' and agency determine third age or fourth age classification in which the nature and degree to which one ages become a matter of individual responsibility (Kirkwood, 2008). In turn this justifies the end of mandatory retirement and the associated raising of the pension age together with individual responsibility for savings and pensions. Yet this also reveals that the two seemingly contradictory tropes of 'ageing as dependency' and 'successful ageing' are two sides of the same coin, with the latter emphasising the importance of avoiding the negative consequences of the former.

Age ideology developed in association with the individualising and civilising processes of modernity and the Enlightenment which emphasise autonomy, separation and privatisation and conversely express horror and disgust at their opposite qualities. This has both an intellectual/philosophical dimension in the Cartesian association of knowledge as 'objective' and 'transcendent' and a psychological dimension. The former embeds the perspective of normative gender (male) and age (youthful prime-of-life) in the definition of knowledge; the latter associates personhood with clear boundaries, autonomy and transcendence of time, with ageing threatening the loss of these attributes. The ideology works at all societal levels: so the 'master narrative of decline' (Gullette, 1997) which defines the process of moving through the lifecourse, seeing ageing as loss and deficit, is also reflected in the bildungsroman, the main form taken by the novel which itself sprung up with modernity. Expressing the symbolic dimension of the capitalist revolution, the bildungsroman rejects the old and the past, focusing on the future and featuring a young (male) hero's social and developmental journey to (self) knowledge, stopping at a point just before maturity. Youth becomes a synonym for progress, productivity and value. Conversely, it is the gendered image of the reviled Hag that distils the negative essence of the age system, representing all that is feared and dreaded (Gullette, 2017; Pickard, 2016). Indeed, it can be argued that all of western modernity's 
conceptual systems, from psychology, medicine, aesthetics and literature, embed and naturalise a problematisation not just of old age but of old women in particular 4 .

One powerful way in which age ideology works is through the concept of 'generations', which encompasses both population 'levels', or microsocial roles within the family such as childhood, adulthood and old age, and also the macro-age cohorts or specific historical periods in which such populations were born (Walker, 1996). Although Karl Mannheim (1952) produced a nuanced sociological account of generations as a concept - for example he stressed that age was insufficient to grasp group identity without a knowledge of other characteristics such as class and place - yet in practice the concept has had the effect of emphasising difference rather than continuity; antagonism, rather than co-operation; homogeneity (of age) over internal difference (gender, class and so on); and a static rather than dynamic relationship between different generations (Nielsen, 2004). The Freudian model of the relationship between generations exemplifies this approach, being both emergent from, and itself shaping, the age system in a conflict mode through the mechanism of the Oedipus complex. In this depiction, the struggle against repression and established power is the property of youth, featuring consciously in much radical politics, from the 1960 s counterculture and student protests, to Jeremy Corbyn's Momentum party's caricature of privileged older people (see the 'Pulling up the Ladder' video in Marsh, 2017) in which youth has also come to stand for social progress, freedom and the good in left-leaning politics. As noted, there are further psychological reasons for the distancing and othering of old age, most particularly the fear of losing the independent, autonomous Cartesian self in the embodiment of old age which generates a visceral antagonism towards ageing (Bordo, 1986). This dread has gathered significant pace during the technological revolution of the past twenty years which has spawned a billion dollar programme aimed at reversing and even stopping both old age and death (Friend, 2017).

\section{Aims and methodology}

This paper builds on previous research on representations of intergenerational inequity, but focuses on an area that has received less attention, namely the depiction of the third age in negative terms. It employs a methodology that draws upon rhetorical and figurative approaches which share with critical discourse analysis a focus on the connection between language, power and ideology (Fairclough, 2013) and which highlight the emotional logic of neoliberalism working through the shaping of affect and attachment in individual subjectivities (Konings, 2015). Rhetorical analysis identifies the strategies through which an argument seeks to persuade its audience by emphasising certain features at the 
expense of others (Winton, 2013). These may involve the use of emotional and affective language or imagery (including cartoons or photographs), the use of polarising 'either/or' frameworks and the selecting of certain perspectives over others to strengthen the viewpoint of the piece (Lazere, 2009). In my use of figurative methodology I draw particularly on the work of Imogen Tyler who has identified the proliferation of 'highly condensed' images or depictions which stereotype and exaggerate (reviled) features of the Other, thereby according value to the groups from which they are differentiated (Tyler, 2008). Such figurations are constructed by means of repetition within and across different media, including newspapers, popular culture, film and literature, political discourses and everyday speech, where particular figures 'accrue affective value in ways that have significant social and political impact' (Tyler, 2008: 19). These figures or tropes are used to generate consent for government policies such as welfare retrenchment or to advocate for policies alternatively favouring or disinvesting from specific groups.

\section{Methods}

\section{Sample}

I initially focused on the Guardian and the Telegraph, chosen for their contrasting political stances. Entering the search terms 'generation(s)', '(baby) boomers' and 'millenials' into the LexisNexis database I found 91 articles (including editorials and op eds) in the Guardian between January 2014 and December 2017 on the subject of intergenerational justice in which most championed the position of younger people (with only 10 being supportive of older generations or not taking sides). By contrast, in the right-of-centre Daily Telegraph, only nine articles during this period focused on intergenerational justice of which eight argued against it as a meaningful concept. I read all such articles in the Telegraph for the three-year period up to December 2017. For the Guardian, which currently does not have a paywall, I read as many as possible of the latter in their online version, for the purpose of noting any accompanying photographic images (to which the database does not give access). I supplemented this with manual searches, including searching specific age-related themes (Brexit, housing, pensions being three examples) and snowballing to include a wide range of sources, including North American publications. The aim of this broad sampling, although starting with contrasting broadsheets, was not to carry out a systematic comparison across media but rather, in line with the aims of figurative methodology, to identify the presence of recurring tropes and figures. I found indeed that the trope of the greedy, selfish and fortunate older person recurred across a range of contemporary media sites, appearing repeatedly in the New York Times, The Atlantic, the Huffington Post, Time, Forbes, and The (London) Times, among others. 
In the Guardian, despite the presence of articles that were balanced or sympathetic to older people, either in terms of the age-war discourse (see, for example Dejevsky, 2014; Okolosie, 2015) or in coverage of other issues such as retirement (see for example Amelia Hill's series of six articles published in January and February 2017), the weight, both rhetorical and quantitative, of the depiction of this theme fell overwhelmingly on the side of 'blaming' the old/third age and this was the message proclaimed in editorials and headlines. Examples include: 'Pensioners living in golden era as income rise outstrips workers' (Collinson, 2017); and: 'Older people have pulled up the ladder: inside England's oldest and youngest towns' (Moss, 2015) which, in both cases, head articles whose content is considerably more judicious and balanced than such headlines might suggest. Nevertheless, a common feature across these articles is a belief that it is both justifiable and meaningful to talk about opposing interests based on age/generation. As one editorial declared: 'And the story here really is about age as opposed to inequality between rich and poor, which was stable during most of these years' (Guardian editorial, March 2016; my emphasis).

This stance is significant for a publication that has spent much of its energies historically identifying and critiquing inequality and, more recently, stood out amongst mainstream UK newspapers in not focusing on calls for austerity as a solution to the financial crash and instead advocating taxing top earners and promoting growth (Berry, 2008). Ultimately such a presentation of social inequality in age-based terms deflects criticism away from the system itself whilst obscuring the true nature and causation of the injustices suffered by people regardless of their age.

In what follows, for the purposes of consistency, I draw mainly on articles published in the Guardian.

\section{Identification of themes}

Across the range of articles published by the Guardian, I identified four main themes, many or some of which recurred in the other publications noted above. These presented the old enjoying either (i) disproportionate political influence, with sub-themes noting their conservative and nationalist tendencies; or (ii) current advantages accruing from favourable present and past policies around housing, wealth including pensions, welfare spending, as well as previous educational opportunities/social mobility. Additionally, there were (iii) psycho-social and affective dimensions, with sub-themes including the old acknowledging their generational culpability and relatedly the young's (justifiable) envy of the old; and (iv) age war as more salient in establishing inequality than class war today. Together these themes compose the argument of 'generational injustice' in which the 'culprits' were depicted most of the time as the older generation. 


\section{Analysis}

\section{Language and imagery}

I was also interested in the tenor of the overall discourse. Across these themes the tone and language was characterised by particularly emotive rhetoric involving powerful metaphors and imagery that often worked through binary couplets associating youth with positive or sympathetic qualities and old age with the opposite. I identified the following couplets across a range of articles contrasting the old with the young as follows: brazen/clobbered; hoarding/shafted; rejoicing/institutionalised beggars; stupid/self-loathing; grey power/jilted; social arthritis/adaptability; gilded/struggling; past/future; selfish/mentally ill; leisurely/busy; gerontocracy/marginalised; drawing up the ladder/hung out to dry.

I also examined a convenience sample of 14 photographic images. Among these were images of old couples, young people, symbolic objects and old women. Whilst I will discuss some of these in more detail below, overall the images often served equally rhetorical purposes in communicating the message of age inequity: a ladder against a wall, with no one on it, a grade-II listed building and an old couple photographed from behind with their arms wrapped around each other, gazing into an estate agent window, in a parody of the young lovers pose, were illustrations for three articles on the ending of social mobility and accessible house ownership. There were also three striking photographs of older women, each of them suggesting, through clothing and appearance, middle- or upper-middle class privilege.

\section{Analysis of themes}

\section{Greater political influence}

Firstly, on the theme of the greater political influence enjoyed by the old, an article by Guardian columnist John Harris (2015) suggests that the policy of the Conservative government entails 'the protection of the benefits and entitlements that apply to older people, while those at the younger end of the age spectrum have their help and protection hacked back'. Citing several policies such as the scrapping of maintenance for poorer university students and the end of housing benefits for the under 21s, compared with the fact that the state pension is now linked to earnings, Harris comments: 'Austerity... is predominantly a young person's game'. This is repeated in discussions on Brexit and the 2017 election (e.g. Coslett, 2016). Whilst the Guardian did not advocate curtailing the vote to older people as in other publications, such as Forbes, the Economist and others (e.g. Chesterton, 2016; Schrieberg, 2016; Stein, 2016) it did advocate lowering the vote to compensate for older voters, as in an editorial which proclaimed: 'The country looks more and more split between the old and the young. It is undemocratic to continue to deny 16-year-olds the vote' (Guardian editorial, 2017). 


\section{Material advantages}

In terms of highlighting the advantages enjoyed by the old over the young, housing stock and pensions stand out. On the theme of housing the following question recurs: 'Dramatic increases in house prices have locked out younger buyers. Does the baby boomer generation now enjoy an unfair level of property wealth?' (Hannah, 2015). The latter article is accompanied by a photograph of a silvery haired woman in her late 70 s or 80 s sitting back in her easy chair, her mouth open in laughter suggestive, when read alongside the text, of selfcongratulatory pleasure, as if personifying today's version of rentier capitalism. Turning to workers' versus pensioners' rights, an article by columnist Philip Inman was headed 'No pay rise? Blame the baby boomers' gilded pension pots' (Inman, 2015). In each of the above cases it is the agency of the older generation that is implicated; not, that is, global economic shifts or government policy. Another was headed: 'pensioners living in golden era as income rise outstrips workers' (Collinson, 2017). The latter article is illustrated by a photograph of an older woman sitting in a deckchair on a yacht, head tipped back as, wearing a broad-brimmed sunhat, she lifts her gaze to the blue horizon in a smile of delight, an image of luxury and light-heartedness that jars particularly with the depiction in the text of the increasing immiseration of working-age people.

\section{Psychological dimensions}

A further theme is that of the affective and psycho-social dimension of intergenerational injustice, ranging from the mild - such as the self-satisfaction of the well-to-do pensioner, indifferent to the young - to suggestions that youth is the victim of vicious psychological manipulation. Guardian Australia millennial columnist, Eleanor Robertson (2015), writes: 'No wonder a quarter of young people are struggling with mental illness. Born into a bizarre world controlled by baby boomers who have comprehensively shafted us, it's a credit to our resilience and adaptability that we've managed to get this far at all.'

Two sub-themes emerged. These are firstly that of baby boomers' selfreproach where some members of this generation, in terms reminiscent of Marx's enlightened bourgeoisie, as well as de Beauvoir's old person (de Beauvoir, 1970), alienated from the Other within herself, pen opinion pieces acknowledging generational culpability. This culpability encompasses all the themes noted above. Guardian columnist Stephen Moss writes: 'We, the generation who took social mobility for granted and enjoyed the sense that we were all in it together as society regathered itself after the Second World War, somehow brought up the drawbridge behind us, making it difficult for less privileged members of the generation that followed us to break through'. Academic and columnist Will Hutton condemns his own generation in very emotive imagery: 
'Having enjoyed a life of free love, free school meals, free universities, defined benefit pensions, mainly full employment and a 40 -year-long housing boom, they are bequeathing their children sky-high house prices, debts and shrivelled pensions. A 60-year-old in 2010 is a very privileged and lucky human being' (Hutton, 2010).'

Many of the above arguments are crystallised in a vivid indictment by former Liberal Democrat Minister Chris Huhne (2013) of his own generation: 'The interests of the young are at risk of being marginalised whilst the old ride proud.... Policy after policy is feeling the hot breath of grey power'. He warns: 'The cost of pandering to pensioners is social arthritis' and concludes with a 'call to arms': 'Someone needs to fight the selfish, short-sighted old. They are the past, not the future' (Huhne, 2013).

The second strand is the somewhat newer theme of envy of the old by the young. For example the Guardian reports the results of a Resolution Foundation study under the heading: 'Millenials wish they had grown up in baby boomers' times' (Busby, September 9, 2017) which found that, despite technological and other social advances, the qualities of stability and security were sufficiently attractive to make one-third wish they had grown up at the time of their parents (see also Coslett in Coslett and Hanson, 2016).

\section{Age war as replacing class war}

Finally, and most importantly perhaps, the theme of age war as class war also appears regularly: it is arguably the indirect message and consistent implication of all of the above themes (and certainly a common refrain in the readers' threads where comments are permitted). The below is a particularly powerful example, by Owen Jones, who sees the old as synonymous with the forces of reaction:

'Here's a nightmare for those of us who want a more just and equal society: the right, in Britain and the rest of Europe, finds a strategy for eternal political dominance: in an ageing society it simply nurtures the support of the older generation, securing the votes of an expanding, highly politically engaged demographic. The young, it abandons...' (Jones, 2016).

One variation on this argument is that the older generation, through voting to leave the EU, are making actual war more likely, whilst the 'Leave' appeal has been likened to the 'Dunkirk' spirit complete with 'nostalgia and xenophobia' (Dakers, 2016). Another is the suggestion that age war not only displaces class war, in the sense meant by Jones, but serves to render it irrelevant, as in the following statement by regular Guardian columnists, and authors of the age-war text Jilted Generation (2013), Ed Howker and Shiv Malik: 'We hope it's clear... that we believe in capitalism, we believe that the mechanisms of the market are appropriate; that the creation of wealth is not just desirable but vital... Capitalism should be celebrated, championed and defended' (2013: 261).

Whilst Mannheim (1952) did indeed suggest similarities between class and generation, highlighting the concepts of generational consciousness (akin to 
Marx's self-conscious 'classes-for-themselves'), the importance of social location within age groups was never lost to him. However, the withering of collective class identities in the context of individualisation renders age and generation as tempting substitutions for these strong identities, especially for younger people.

\section{Discussion}

Cumulatively, and through the use of powerful rhetorical techniques, these articles weave a multi-layered attack on the third age. They thereby also construct a case that (i) there are meaningful age-based divisions that relate to inequality and advantage in direct ways; (ii) generations stand in conflicting classes characterised by difference and in some cases by direct antagonism; and (iii) age and generation are coherent categories not just for explaining injustice but also for attributing agency and blame. They contain many assumptions, presented as commonsense or fair/progressive but which are in fact age ideological, such as the fact that it is 'natural' and 'right' for young people to do better in socio-economic terms than their parents and relatedly that youth and progress are associated (both of these arguments are explicitly made in an article by Guardian economics editor Larry Elliott (2016), for example); and finally that age is inferior to youth in a host of ways, representing the future, and progress, as it does. The third age, formerly an aspirational identity, is thereby profoundly devalued. Of course such a shift in meaning over time reflects the shifts in governmentality shaping new conditions of possibility in which old age may be discussed; the critique of old age as privilege is only possible as a result of the emergence of the third-age category which in turn has distinguished itself from the devalued fourth age.

The emotional logic of age ideology is amplified by the appearance of such tropes and figures across genres, comprising broadsheet reporting but also fiction and fantasy. For example, where M Night Shyamalan's 2015 horror movie 'The Visit', depicting menacing elderly grandparents bent on murdering their grandchildren, has been called 'the most gerontophobic film ever made' (Robey, 2015) milder wisps of this same nightmarish quality drift through some of the longer pieces of serious journalism which play on the idea of the privileged third age contrasting with the hopelessness of youth as a kind of monstrous reversal of natural law. For example, in Harris' (2015) article (cited in theme one, above), in which he visits Christchurch, Dorset, the English constituency with the highest proportion of 'pensioners', he depicts an atmosphere which, layer upon layer, and in a play of intertextuality, builds up a sense of something ominous and sinister. The streets are full of the old not the young, the old people are deaf to the 'great howls of pain' of the young, one woman aged 91, says 'Life is what you make it' before complaining about the mothers raising numerous children on benefits, an implied grotesque reversal of entitlement. The third age is, here, arguably as monstrous as the fourth, where the association of Alzheimer's Disease with, for 
example, zombies, is a well-used trope (Gullette, 2017). The prominence given to older women in such texts, including in photographic imagery, not only draws attention to the gendered aspect of hostility to old age but also indicates that the reviled figure of the Hag comprises two aspects: tragic and pitiable, on the one hand, as in the fourth age, and powerful and threatening on the other, as in the third age. There are also resonances historically with representations of social degeneration that blossomed a century ago (Pick, 1993), and link today's older generations with the aliens, criminals, lunatics and demi-mondaine of the fin-desiècle who threatened to stand in the way of capitalism's upward and expansionist arc. This points to a key meaning of the generational progress rhetoric, whereby it is largely framed in terms of material improvement, specifically the ability to consume more, in accordance with capitalism's project of perpetual growth, and which is deeply threatened by the prospect of the shrinking of the youthful market.

\section{Conclusion}

Repetition of these tropes across the media have a powerful effect on shaping public views; when the articles cited above invite readers comments they invariably lead to comments sharply polarised by age (see also Hurley et al., 2017). Yet those who gain from this intergenerational warfare discourse are big business, corporate finance, transnational capitalism and their representatives such as the World Bank and the IMF, as well as all interests who benefit from a scaled down social infrastructure. This discourse feeds into, and in turn draws from, the culture of emotion, especially that of resentment and the abjectification of less deserving others, that is key to the dynamics of neoliberal capitalism (Hoggett et al., 2013; Konings, 2015; Tyler, 2008) and to which progressive thinkers, in the emotive style of broadsheet columnists, as well as conservative interests, contribute. At the same time it considerably reduces the likelihood of a social policy towards ageing which alone will address the challenges and issues relating to the demographic shift in ageing, and potentially super-ageing, societies such as that of the UK (Walker, 2017).

Nor should there be any illusion that the effects of the age system are benign towards the young, even in the short term. Indeed, encouraged by generational antagonism towards a narrow focus on 'missed opportunities' young people, traditionally 'rebels' who have questioned the norms and practices of society, have been encouraged to divert their critique along more conservative channels, complaining about being denied a piece of the pie: the regular jobs, mortgages and accomplishments of conventional adulthood. If, as Mannheim (1952) identified, the necessity of 'fresh contacts' with established ways of knowing, doing and being associates change and renewal with the emergence of new generations then this picture suggests rather the entrenchment of neoliberal values in younger 
populations and the defeat of alternative visions of the 'good life'. Where the observed 'biographical uncertainty' that characterises many young people's lives might otherwise have resulted in a 'modality that denies the significance of the traditional adult models and roles' - foregrounding 'the search for alternative life paths' (Leccardi and Rampazi, 1993: 359) - instead, such discourses help to keep aspirations conservative and capitalism-friendly. 'I think I may be more traditional than Michele,' reflects Rhiannon Lucy Coslett, the millennial columnist, when she and baby-boomer journalist Michele Hanson compared fortunes. Whilst recognising the cause, she cannot evade the effects; 'I crave marriage and our own house one day, perhaps because they seem so off limits. If these things were not only expected of me but also easy enough to attain, as they were in Michele's youth, perhaps I would reject them' (Coslett and Hanson, 2016). Indeed if, as Boltanski and Chiapello (2005) argue, each phase or extension of capitalism requires a new ideological justification, the trope of generational war is proving to be a key weapon in rendering alternatives to the values of a market society seem unthinkable.

Yet even so conflict is not inevitable and there is still a broad social concern, shared by all ages, for provision for older people (Hurley et al., 2017) as well as for future generations (Graham et al., 2017), as revealed year on year in Social Attitudes surveys. It is this commonality and shared sympathy that could be emphasised, via some modification of tone by the mainstream media. For this to happen, however, will require recognition - including by the 'progressive' media - of the importance of the age system in shaping inequality as well as the age ideology that, underpinning it, makes of the older generation the 'enemy'.

\section{Acknowledgements}

Earlier versions of this paper were presented at an invited seminar held at the Tokyo Metropolitan Institute of Gerontology in April 2016 and at the American Sociological Association Conference, August 2017. Many thanks to Dr Tomoko Wakui for inviting me to Tokyo and thanks to Professor Carroll Estes for her warm feedback and particularly helpful comments at the ASA meeting.

\section{Notes}

1 Comments by an Australian entrepreneur blaming young people's failure to get on the housing ladder on their over-developed and impecunious sense of entitlement (summed up in a notorious representation of them eating avocado toast for a (self-indulgent) brunch), this was initially reported as an age war between boomers and millennials (Coslett, 2017): until it emerged that the entrepreneur was only 35 years old.

2 Bristow (2015) identifies 2010 as the start of the construction of the baby boomer generation as a 'problem' in the UK media, thus linking it with the 'problem of old age' discourse.

3 Age-based statistics miss other nuances. For example, although 'Generation Rent', a term coined by the media to convey the particular difficulties that the millenials experience in buying their own property, is reflected in the data that 48 per cent of those aged 25-34 are renting as compared to 29 per cent of all UK adults, this is not the entire picture. $25-34$ 
year-old renters are generally better off than renters in the population as a whole (FCA, 2017). Similarly the unique precarity of poor older people is missed here.

4 Although it is beyond the scope of the paper to expand on this, see Pickard, 2016.

\section{References}

Beauvoir, S. de (1996) [1970], The Coming of Age. New York: Norton

Best, S. (2008), Social Problems, New York: Norton

Bordo, S. (1986), The Cartesian masculinisation of thought, Signs, 11, 3, 439-56.

Boltanski, L. and Chiapello, E. (2005), The New Spirit of Capitalism, London: Verso

Bristow, J. (2015), Baby Boomers and Generational Conflict, London: Palgrave Macmillan.

Busby, M. (2017), 'Millenials wish they had grown up in baby boomers' times - survey', The Guardian, 9 September.

Calasanti, T. M. and Slevin, K. F. (eds) (2006), Age Matters: realigning feminist thinking, London: Routledge.

Callahan, D. (1987), Setting Limits: medical goals in an ageing society, New York: Simon and Schuster.

Chesterton, G. (2016), 'We should ban old people from voting', GQ magazine, 14 June.

Cole, T. R. (1992), The Journey of Life. Cambridge: Cambridge University Press.

Cole, T. R. (1989), Generational equity in America: a cultural historian's perspective, Social Science and Medicine, 29, 3, pp. 377-83.

Collinson, P. (2017), 'Pensioners living in golden era as income rise outstrips workers', The Guardian, 8 August.

Coslett, R. L (2016), Family rifts over Brexit: 'I can barely look at my parents', The Guardian, 26 June.

Coslett, R. L. and Hanson, M. (2016), 'A millennial and a baby boomer trade places: "I can't help but feel a stab of envy", The Guardian, 12 March.

Coslett, R. L (2017), 'Stop spending money on avocados? Good idea, I'll have a house deposit by 2117 ', The Guardian, 16 May.

Cunningham, H. (2006), The invention of childhood, London: BBC

Dakers, S. (2016), Why Brexit makes a visceral appeal to the older generation's psyche, The Guardian, 21 June.

Dejevsky, M. (2014), 'Calling all pensioners: it is time to stand up for your rights', The Guardian, 6 January.

Dorling, D. (2014), Inequality and the One Per Cent, London: Verso.

Elliott, L. (2016), Each generation should be better off than their parents? Think again, The Guardian, 14 February.

Fairclough, N. (2013), Critical Discourse Analysis, London: Routledge

Financial Conduct Authority (2017), Understanding the Financial Lives of UK adults https://www.fca.org.uk/publications/research/understanding-financial-lives-uk-adults

Fealy, G., McNamara, M., Treacy, M. P. and Lyons, I. (2012), Constructing ageing and age identities: a case of newspaper discourses, Ageing and Society, 32, 1, 85-102.

Friend, T. (2017), The god pill: Silicon Valley's quest for eternal life, The New Yorker, 3 April.

Graham, H., Bland, M. J., Cookson, R., Kanaan, M. and White, P. C. L. (2017), Do people favour policies that protect future generations? Evidence from a British Survey of Adults, Journal of Social Policy, 46, 3, 423-445.

Guardian Editorial (2016), 'The Guardian view on millenials: a deepening age divide and the growing pains of Generation Y', The Guardian, March 11.

Guardian Editorial (2017), The Guardian view on the voting age: time to lower it to 16, The Guardian, 8 June.

Gullette, M. M. (1997), Declining to Decline, University of Virginia Press: Charlottesville.

Gullette, M. M. (2017), Ending Ageism: or, how not to shoot old people. New Jersey and London: Rutgers University Press. 
Hannah, F. (2015), 'Homeownership: the generation that had it so good', The Guardian, 4 August.

Happer, C. and Philo, G. (2013), The role of the media in the construction of public belief and social change, Journal of Social and Political Psychology, 1, 1, 321-336.

Harris, J. (2015) '"They want more than we did" - how the Tories made age our biggest divide', The Guardian, July 17.

Hoggett, P., Wilkinson, H. and Beedell, P. (2013), Fairness and the politics of resentment, Journal of Social Policy, 42, 3, 567-585

Howker, E. and Malik, S. (2013), Jilted Generation: how Britain bankrupted its youth, Second Edition, London: Icon Books.

Huhne, C. (2013), 'Someone needs to fight the selfish short-sighted old', The Guardian, December 22.

Hurley, K., Breheny, M. and Tuffin, K. (2017), Intergenerational inequity arguments and the implications for state-funded financial support of older people, Ageing and Society, 37, 3, $561-580$

Hutton, W. (2010), 'The baby boomers and the price of personal freedom', The Observer, 22 August.

Inman, P. (2015), 'No pay rise? Blame the baby boomers' gilded pension pots', The Guardian 14 September.

Jones, O. (2016), 'A war of the generations is not a solution - hope is', The Guardian, 9 March.

Katz, S. (1996), Disciplining Old Age. Charlottesville, VA: University of Virginia Press.

Konings, M. (2015), The Emotional Logic of Capitalism, California: Stanford University Press.

Lazere, D. (2009), Reading and writing for civic literacy, Boulder: Paradigm Publishers.

Leccardi, C. and Rampazi, M. (1993), Past and future in young women's experience of time Time and Society 2, 3, 353-379.

Macnicol, J. (2015a), Intergenerational Equity: historical reconstructions. In Torp, C (ed) Challenges of Ageing, London: Palgrave, pp. 229-249.

Macnicol, J. (2015b), Neoliberalising old age, Cambridge: Cambridge University Press.

Nielsen, H. B. (2004), Noisy Girls: new subjectivities and old gender discourses, Young 12, 1, 9-30.

Mannheim, K. (1952) [1927], The problem of generations. In Essays on the Sociology of Knowledge, London, Routledge and Kegan Paul.

Marsh, S. (2017), 'Momentum's video parodies older voters discussing Corbyn's policies', The Guardian, 28 July.

Moss, S. (2015), 'Confessions of a baby boomer: we weren't that lucky, but we were stupid', The Guardian, 19 August.

Organisation for Economic Cooperation and Development (OECD) (2017), Pensions at a glance: how does the United Kingdom compare? http://www.oecd.org/ unitedkingdom/PAG2017-GBR.pdf [accessed 26/1/2018]

Okolosie, L. (2015), When it comes to austerity, the generation clash is a myth. The Guardian, 29 September.

Phillipson, C. (1996), Intergenerational conflicts and the welfare state: American and British perspectives. In The New Generational Contract: intergenerational relations, old age and welfare, London: UCL Press, pp. 206-220

Pick, D. (1993), Faces of Degeneration: a European Disorder, c. 1848-1918, Cambridge, Cambridge University Press.

Pickard, S. (2016), Age Studies: how we age and are aged through the lifecourse, London, Sage.

Robey, T. (2015), The Visit review: "the most gerontophobic film ever made", The Telegraph, 9 September

Rowe, J. W. and Kahn, R. L. (1987), Human ageing: usual and successful, Science, 237, 143-9.

Schrieberg, D. (2016), Angry old people shouldn't be allowed to vote, Forbes, 1 July

Sinclair, D. (2015), The myth of the baby boomer, Ready for ageing alliance, http:// www.cpa.org.uk/cpa/docs/R4AA/R4AA-The_myth_of_the_baby_boomer.pdf [accessed $01 / 02 / 2017]$ 
Social Attitudes surveys. (See National Centre for Social Research at http://natcen. ac.uk/our-research/research/british-social-attitudes/)

Stein, J. (2016), 'Why older people shouldn't vote - and other ideas unpopular with my parents', Time, 18 August

Thane, P. (2006), The 'scandal' of women's pensions in Britain: how did it come about? http://www.historyandpolicy.org/policy-papers/papers/the-scandal-of-womenspensions-in-britain-how-did-it-come-about [accessed o1/o1/2016]

TUC (2013), Women over 50: work and pay, London, TUC.

Tyler, I. (2008), Chav mum chav scum, Feminist Media Studies, 8, 1, 17-34

Walker, A. (1996), Introduction: the new generational contract. In Walker, A. (ed), The New Generational Contract: intergenerational relations, old age and welfare, London: UCL Press, pp. 1-9

Walker, A. (2017), Why the UK needs a social policy on ageing, Journal of Social Policy, https://doi.org/10.1017/Soo47279417000320

Winton, S. (2013), Rhetorical analysis in critical policy research, International Journal of Qualitative Studies in Education, 26, 2, 158-77 